\title{
Environmental factors that influence the distribution, size, and biotic relationships of the Christmas tree coral Antipathes dendrochristos in the Southern California Bight
}

\author{
David D. Huff ${ }^{1,2, *}$, Mary M. Yoklavich ${ }^{1}$, Milton S. Love ${ }^{3}$, Diana L. Watters ${ }^{1}$, \\ Fei Chai ${ }^{4}$, Steven T. Lindley ${ }^{1}$ \\ ${ }^{1}$ Fisheries Ecology Division, Southwest Fisheries Science Center, National Oceanic and Atmospheric Administration, \\ Santa Cruz, California 95060, USA \\ ${ }^{2}$ Institute of Marine Sciences, University of California, Santa Cruz, California 65064, USA \\ ${ }^{3}$ Marine Science Institute, University of California, Santa Barbara, California 93106-6150, USA \\ ${ }^{4}$ School of Marine Sciences, University of Maine, Orono, Maine 04469-5706, USA
}

\begin{abstract}
The Christmas tree coral Antipathes dendrochristos is a recently discovered black coral species that represents a habitat associated with numerous sensitive taxa in the Southern California Bight. We evaluated whether broad-scale oceanographic features influence coral density and size by selecting from among generalized additive models (for density) and generalized linear models (for size) that represented competing hypotheses. We constructed models to predict coral density and size using depth, seafloor slope, surface primary productivity, bottom currents, ocean temperature, salinity, and dissolved oxygen as candidate covariates. Specifically, we evaluated hypothesized links between pelagic production and benthic coral utilization and between bottom currents and larval coral dispersal. Our analysis revealed that high surface primary productivity in combination with depth and January currents are important predictors of Christmas tree coral density. Higher coral density coincided with greater chlorophyll persistence and optimal depths near $400 \mathrm{~m}$. Surface productivity increasingly was associated with Christmas tree corals at shallower depths. Our results supported the hypothesis that ocean currents affect coral density via larval dispersal mechanisms. The selected coral size models responded to similar covariates, corroborating coral density results. Fish and invertebrate ordinations indicated that Christmas tree corals were widely distributed across environmental gradients and that Christmas tree corals cooccurred with several demersal fish and invertebrates. Several predicted coral hotspots remain unprotected from fishing, particularly in areas adjacent to highly populated portions of the Southern California Bight. These regions should be targeted by future studies to confirm the presence of Christmas tree coral communities and to evaluate their vulnerability.
\end{abstract}

KEY WORDS: Antipatharia $\cdot$ Black corals · Deep sea corals $\cdot$ Cold-water corals $\cdot$ ROMS $\cdot$ Predictive modeling $\cdot$ Indirect gradient analysis

Resale or republication not permitted without written consent of the publisher

\section{INTRODUCTION}

The black corals (order: Antipatharia) represent one of the least studied groups of non-scleractinian corals, and until recently, data regarding their distri- bution and environmental associations along the continental Pacific coast of North America were largely unavailable (Yoklavich \& Love 2005, Tissot et al. 2006, Lundsten et al. 2009). Although cold-water black corals include many commercially valuable 
species, they may also occupy important habitats that support a variety of co-occurring taxa (Stone 2006, Bo et al. 2008, 2012). Opresko (2005) recently published a new black coral species description, the Christmas tree coral Antipathes dendrochristos (Fig. 1), that was collected from the Southern California Bight. The Christmas tree coral is an uncommon, longlived, colonial coral that typically supports a diverse biological assemblage and may represent a habitat that is acutely vulnerable to benthic fishing activities and other anthropogenic disturbances (Yoklavich \& Love 2005, Tissot et al. 2006, Love et al. 2007).

The distribution and habitat associations of many coral species are poorly understood. Describing these relationships advances progress toward ecosystembased resource management (Pikitch et al. 2004), marine spatial planning, and sustainable fisheries practices (Crowder et al. 2006, Halpern et al. 2008). This is especially true in the Southern California Bight, which is among the most heavily exploited areas on the west coast of North America for purposes such as commercial shipping, coastal development, recreational boating, fishing, and municipal discharge. However, characterizing cold-water coral habitats is inherently difficult because of the complex nature of marine ecosystems in which multiple factors affect coral-habitat associations, the range of spatial and temporal scales over which habitat

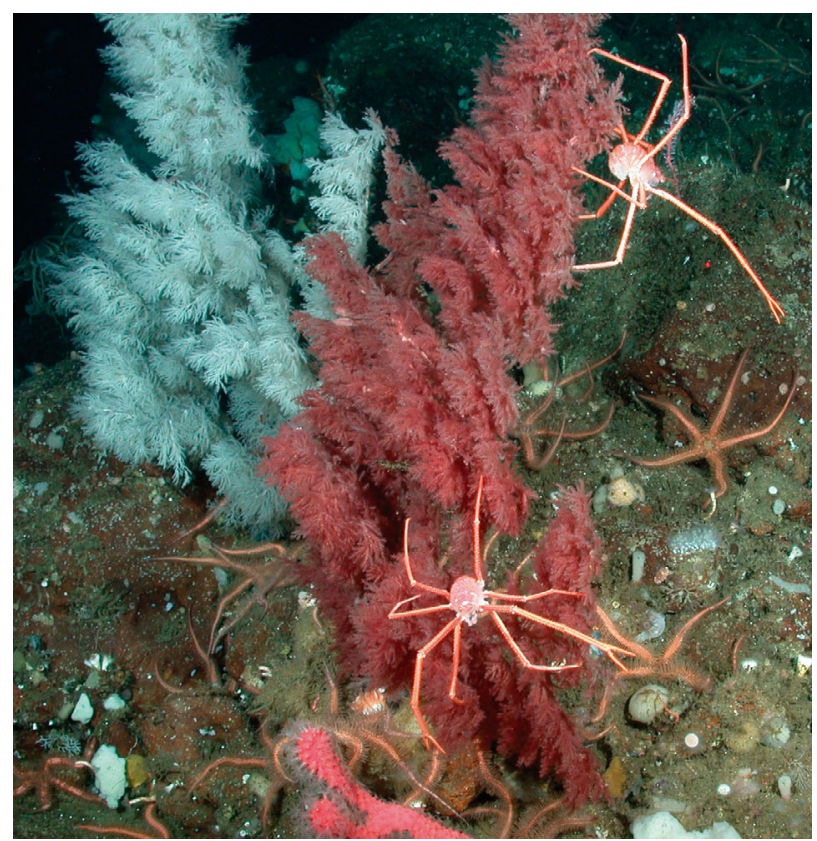

Fig. 1. Antipathes dendrochristos. In situ red and white color variants of Christmas tree coral colonies within the Southern California Bight. These coral colonies were found at $300 \mathrm{~m}$ depth and were approximately $50 \mathrm{~cm}$ tall features are relevant, and the practical difficulties of sampling deep-sea habitats. Increased use of manned submersibles and remotely operated vehicles to survey deep-sea fisheries habitat has provided unique and valuable data sets that have been gleaned from archived video (Yoklavich \& O'Connell 2008). These spatially explicit data include numerous species of fishes and invertebrates, their sizes, densities, and associated habitat components. A challenge in modeling coral distribution and abundance has been the dearth of environmental data that are relevant to corals on a spatial scale needed to characterize components of coral habitat across broad regions. Methodological advances in oceanographic modeling, such as regional oceanographic modeling systems (ROMS), provide environmental parameters near the seafloor that are relevant to benthic species (Shchepetkin \& McWilliams 2005). This information is available over a number of time intervals and across expansive seafloor landscapes. Combining visual observations with oceanographic model output or other broad-scale data may greatly contribute to the emerging body of research into regional and global predictive habitat modeling for cold-water corals, many of which remain among the most enigmatic organisms in the deep ocean (Davies \& Guinotte 2011, Manderson et al. 2011).

The geographic distribution of Christmas tree corals may be influenced by various habitat features. Hard substratum is a basic requirement that provides an attachment surface, which must be stable in strong currents and large enough to support colonies up to $2.5 \mathrm{~m}$ in height. Seafloor slope measurements may distinguish features such as ridges and mounts that are associated with hard substratum. Water temperature is perhaps the most significant feature that influences cold-water coral distribution; species tend to colonize at depths that have an optimal temperature range (Roberts et al. 2009). While the majority of black coral species occur in deep water (down to $8600 \mathrm{~m}$ ), Christmas tree corals occur shallower from 50 to $860 \mathrm{~m}$ (this study). Although direct studies of calcification rates and environmental growth controls are limited, it is likely that food availability also affects the geographic range of corals (Sherwood et al. 2005). Corals in deeper waters that are farther from surface production have been demonstrated to grow more slowly than those in shallow waters closer to the euphotic zone (Roberts et al. 2009). Therefore, habitat features that approximate surface production or link pelagic production to benthic coral consumption may serve as predictors of coral distribution and growth (Frederiksen et al. 1992, Klitgaard et al. 1997, Bryan \& Metaxas 
2007). Water currents are also an important environmental factor because they may (1) affect the routes by which the corals receive food particles, (2) prevent fouling of corals with sediment or cause physical damage, and (3) influence larval dispersal and connectivity among suitable habitat patches (Scheltema 1986, White et al. 2005, Davies et al. 2009). Dissolved oxygen and salinity also may affect cold-water coral distributions, but these variables are expected to have less direct impact than the other habitat components because salinity is relatively constant in deep water, and cold-water corals generally are able to tolerate a broad range of oxygen levels (Childress \& Seibel 1998). On a global scale, ocean chemistry may control the distribution patterns of cold-water scleractinian corals in particular, relative to the depth of the aragonite saturation horizon (Clark et al. 2006, Guinotte et al. 2006, Yesson et al. 2012).

In the present study, we developed predictive models to geographically delineate areas in the Southern California Bight that coincided with hypothesized Christmas tree coral environmental constraints. We used data on size and density of corals from archived video surveys, together with potentially relevant environmental features that included depth, seafloor slope, surface primary productivity, bottom currents, ocean temperature, salinity, and dissolved oxygen. We modeled the density and size of Christmas tree corals using generalized additive models (GAMs; coral density) and generalized linear models (GLMs; coral size). Specifically, we assessed the support of our statistical models for hypotheses regarding food availability and coral dispersal. We examined response curves derived from selected model covariates, and identified patterns in covariate distributions that were likely to comprise important environmental constraints. We also described some of the biotic associations of Christmas tree corals relative to predictive model covariates by constructing non-metric multidimensional scaling (NMS) plots that depicted benthic community structure in the context of environmental gradients.

\section{MATERIALS AND METHODS}

\section{Study area}

Our study area in the Southern California Bight lies from just south of Point Conception to San Diego, California, USA (approximately $121^{\circ} \mathrm{W}, 34.5^{\circ} \mathrm{N}$ to $\left.117^{\circ} \mathrm{W}, 32^{\circ} \mathrm{N}\right)$; it encompasses the Channel Islands and numerous ridges and seamounts (Fig. 2). The interior of the Southern California Bight comprises surface water with lower chlorophyll concentrations bounded by frontal regions on the northern and western margins that are adjacent to cooler and more chlorophyll-rich water (Eppley 1992). At the southern boundary of the Bight, a chlorophyll gradient known as the Ensenada Front separates relatively higher chlorophyll waters in the colder water directly to the north of the front and lower chlorophyll waters to the south (Moser \& Smith 1993). Wind stress and Ekman transport are minimal in the Bight relative to the rest of the California Current region, and stratification may be substantial in both winter and summer (Husby \& Nelson 1982). The areas adjacent to the coast commonly exhibit colder surface water and greater chlorophyll concentrations that are indicative of local upwelling; suspended organic matter concentrations are consistently higher inshore than farther offshore in the Bight (Mullin 1986, Barnett \& Jahn 1987). Circulation in the Southern California Bight is generally cyclonic, a result of the interaction between the southeastward California Current and Southern California Countercurrent. However, most of the Bight is characterized by complex current circulation patterns. Large variations in current strength have been observed over the course of weeks to months, and it is possible that during occasional extreme fluctuations the entire Bight could be flushed within a few weeks (Hickey 1992). More than 5000 benthic invertebrate species and approximately 500 fish species inhabit this region, presumably because the Bight comprises ocean conditions representative of both the northern Oregonian and southern San Diegan provinces and because a wide variety of marine habitat types are found in this area (Dailey et al. 1993).

\section{Data sources}

We conducted 457 underwater video transect surveys of demersal communities in the Southern California Bight using a manned submersible ('Delta') and a remotely operated vehicle ('Kraken 2') during September and October from 1999 to 2010 (see Tissot et al. 2006 and Love et al. 2009 for details on the 'Delta' survey vehicle and methods). Seafloor maps of substratum types and other past geophysical surveys were used to identify and select locations with rocky habitats (Greene et al. 1999, 2003). Location, habitat features (seafloor depth and substratum type), Christmas tree corals, sponges, other coral taxa, and fishes were recorded and quantified for each $2 \mathrm{~m}$ wide 


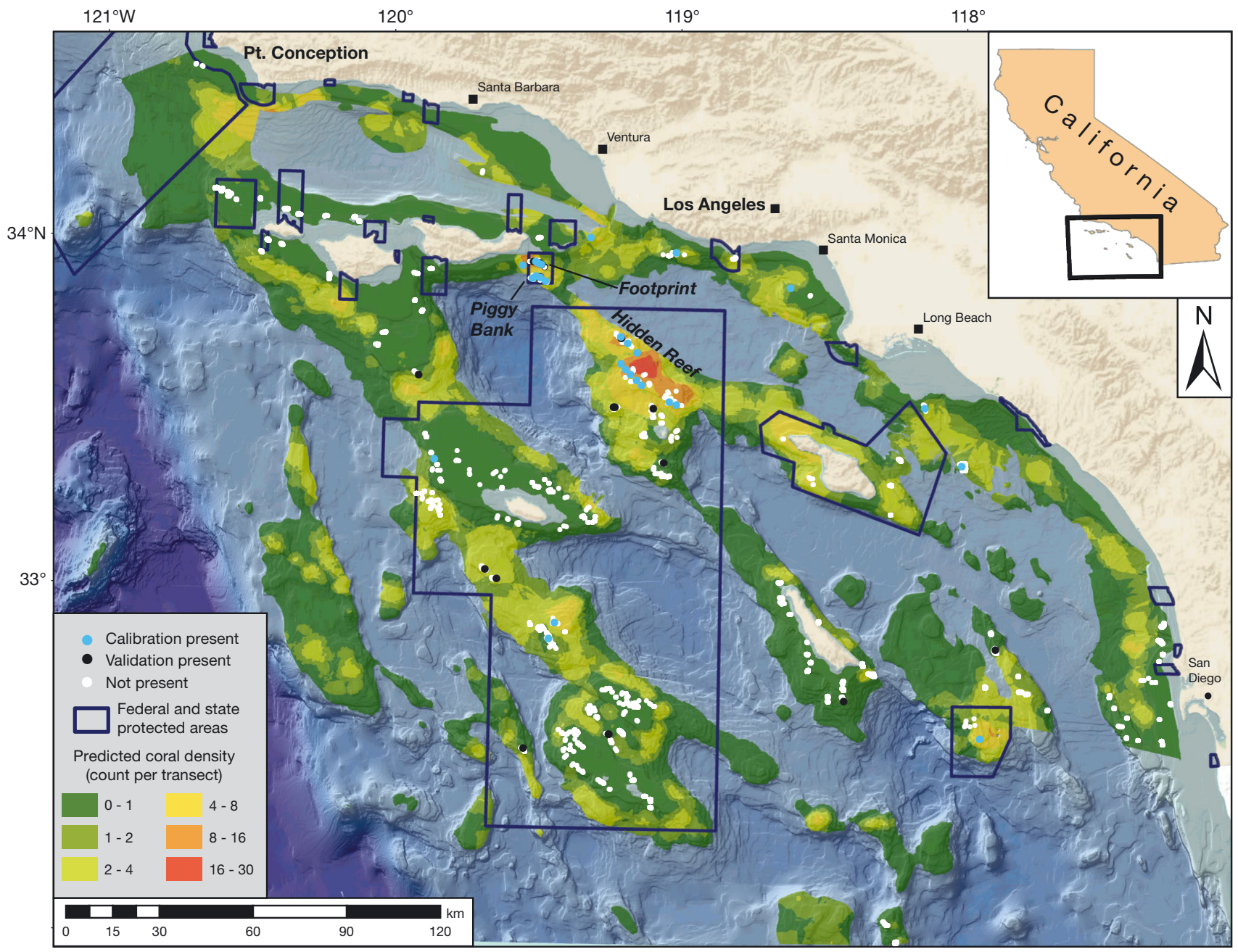

Fig. 2. Study area in the Southern California Bight. Density (coral colonies per transect group) predicted from a generalized additive model, presence and absence from our calibration data set and from a National Ocean Service/National Marine Fisheries Service independent data set of Christmas tree corals, along with boundaries of areas closed to fishing also shown. Mean transect area $=740 \mathrm{~m}^{2}$

'Delta' and 'Kraken 2' video transect. Transect lengths ranged from 75 to $2334 \mathrm{~m}$, with a mean $\pm \mathrm{SD}$ transect length of $370 \pm 75 \mathrm{~m}$. The proportion of hard substratum type (i.e. isolated high-relief rock pinnacle, rocky outcrop with 30 to $80^{\circ}$ relief, flat rock, boulder [>25.5 cm], and cobble [6.5-25.5 cm]) was estimated for each transect. When Christmas tree corals were present and the video frame height and quality were adequate ( $\mathrm{n}=117$ transects), we measured the height of individual Christmas tree coral colonies.

We generated oceanographic potential covariates at seafloor depth for temperature, salinity, dissolved oxygen saturation, and northward (meridional) and eastward (zonal) current velocities from oceanographic models originally developed for the northern Pacific Ocean. The physical model covariates are based on the ROMS (Xiu et al. 2010, Xiu \& Chai
2011), and the biogeochemical covariate (oxygen) is based on the Carbon, $\mathrm{Si}(\mathrm{OH})_{4}$, Nitrogen Ecosystem model (CoSiNE; Chai et al. 2002); both models have a horizontal resolution of $0.125^{\circ}(\sim 14 \mathrm{~km})$. This coupled ROMS-CoSiNE model configuration has been evaluated repeatedly with independent observations throughout the North Pacific (Polovina et al. 2008, Bidigare et al. 2009, Chai et al. 2009, Liu \& Chai 2009, Xiu et al. 2012). With the exception of current velocity, oceanographic data were averaged values for 2004 to 2006; for current velocities, we used monthly averaged values for 2004 to 2006 . We developed a climatology over a recent $3 \mathrm{yr}$ period for temperature, salinity, and dissolved oxygen for several reasons. First, Christmas tree corals are long-lived and sessile; their size and distribution integrates a complex suite of conditions over the course of their existence (Love 
et al. 2007). Therefore, we argue that averaged values for these variables represented the coral colonies' experience more realistically than a snapshot when the sample was taken. Second, conditions near the ocean floor within the California Bight have relatively low variability over time with regard to salinity, temperature, and dissolved oxygen; preliminary analyses indicated that most of the variation in these values occurred spatially. Finally, we chose a recent 3 yr period because it overlaps the data collection time period, encompasses much of the temporal variation, and represents recent conditions that are more relevant to potential management decisions. Alternatively, preliminary analyses indicated that current velocity data varied substantially on a monthly basis. Furthermore, we wished to examine whether the current velocity at a particular time of year would yield an informative covariate for our models, in addition to potentially indicating larval release timing that we may investigate in future studies. ROMS current velocities were not intended to represent fine-scale effects; rather, these values were intended to represent a more general description of current velocity direction and magnitude broadly across a given transect region.

We also examined a metric of surface productivity intended to coarsely represent organic material available to benthic organisms, the chlorophyll persistence index (CPI). CPI data, which quantify chlorophyll a variance in terms of the frequency of anomalies that exceed $1 \mathrm{SD}$ from the mean relative to a spatial model for the ecosystem, were obtained from Suryan et al. (2012). Depth and corresponding slope and profile (curvature in the direction of maximum slope) values (using Spatial Analyst; ESRI ${ }^{\mathrm{TM}}$ $\operatorname{ArcMAP}^{\circledR}$ v.10) were derived from a $90 \mathrm{~m}$ resolution digital elevation model downloaded from the NOAA National Geophysical Data Center (Eakins 2003). Spatial data manipulation, tabulation, and interpolation were implemented using ESRI ${ }^{\mathrm{TM}} \operatorname{ArcMAP}^{\circledR}{ }_{\mathrm{V}} \mathrm{10}$.

\section{Data analysis}

Many of the video transects overlapped spatially, and examination of Moran's ' $\mathrm{I}$ ' plots indicated a highly clumped spatial distribution of Christmas tree corals. Therefore, we combined transects and averaged coral density [count/(transect width $\times$ transect length)] and substratum values based on horizontal spatial proximity and depth. We calculated Euclidian distances among transects based on latitude, longitude, and depth ('vegdist' function in $\mathrm{R}_{i}$ Oksanen
2004). We grouped transects with hierarchical cluster analysis using Ward's method and cut the tree at 60 groups ('hclust' function in $\mathrm{R}_{i}$ Maechler et al. 2012) based on visual examination of the spatial arrangements of the groups and global Moran's test for spatial autocorrelation of both transect locations and coral density simultaneously ('moran.test' function in $\mathrm{R}_{i}$ Bivand et al. 2012). We chose the largest number of transect groups $(n=60)$ which did not exhibit a significantly clustered spatial pattern as our sample units. Of these transect groups, 25 had corresponding coral size data.

We developed predictive models based on the hypothesis that the distribution of Christmas tree corals was largely controlled by environmental factors (Guisan \& Zimmermann 2000). Our measured response variables were the density (mean count per transect group area) and size (mean individual colony height per transect group) of Christmas tree corals. We described the relationship of coral density with environmental covariates using GAMs (Hastie \& Tibshirani 1990, Wood 2000) because we had an adequate quantity of coral density data for this technique and because GAMs are more flexible and can capture the expected non-linear response of organisms to environmental gradients better than strictly linear methods (Hastie \& Tibshirani 1990, Austin 2002). We constructed GAMs ('mgcv' package; Wood 2004) with a quasi-Poisson error distribution to allow for over-dispersion in inferences based on density data and a log link (Godambe \& Heyde 1987, Ver Hoef \& Boveng 2007).

We developed GLMs (Chambers \& Hastie 1993) to describe size-environment relationships because we had fewer size data and because this method is a linear technique that may use fewer data than its nonparametric, data-hungry extension, the GAM. GLMs were developed with a Gaussian error distribution and a log link. We completed both modeling exercises using R software (Version 2.15.1; Ihaka \& Gentleman 1996). We selected models based on the lowest values of Akaike's information criterion (AIC) using the 'MuMIn' package (Bartoń 2011). We used $k$-fold crossvalidation in which we split the data into equal-sized parts and then iteratively used part of the data to fit the model and a different part to test it (Hastie et al. 2009). We repeated each $k$-fold cross validation process 500 times and examined the distribution of the coefficient of determination and other model evaluation values. We also evaluated the results of our coral density model with an independent presenceabsence dataset for the Southern California Bight (P. Etnoyer \& K. Stierhoff unpublished data). 
We identified groups of covariates that were collinear $(|\mathrm{r}|<0.7$; Dormann et al. 2013) and then selected the single covariate from each group that had the strongest relationship with the response variable (Christmas tree coral density or size) as determined by non-parametric regression; we chose the single covariates with the greatest leave-one-out jack-knifed coefficient of determination $\left(\mathrm{R}^{2}\right)$. We chose candidate covariates from among 3 groups, in addition to CPI, which represented primary productivity at the ocean's surface. The first highly correlated covariate group comprised temperature, oxygen, and salinity. The second covariate group included monthly current components that exhibited a substantial relationship $\left(\mathrm{R}^{2}>0.1\right)$ to the response variable. The third group represented the benthic physical setting and included depth, slope, and profile. Finally, we included an interaction between depth and our productivity covariate (CPI), by which we examined the potential effect of organic particle flux over depth on the response variable (coral size or density). Because each of the candidate covariates had a biologically realistic basis for being considered, we constructed all subsets of the models with 4 or fewer covariates and included the main effects when an interaction was considered. We conducted data exploration by visualizing various characteristics of the datasets approximately following Zuur et al. (2007).

No region-wide datasets of seafloor substratum types were available at the appropriate scale and resolution. We therefore constructed a map of predicted coral density only for areas identified as either 'ridge,' 'shelf,' or 'flank' megahabitat features (Greene et al. 2007). These categories represent physiography and depth on a spatial scale of a few to 10 s of kilometers. Ridge habitats are characterized as crests (including seamounts) that are 200 to $2500 \mathrm{~m}$ deep, continental and island shelf habitats are 0 to $200 \mathrm{~m}$ deep, and flanks are continental slope or basin/island margins that are 200 to $3000 \mathrm{~m}$ deep. Christmas tree corals in our database only occurred within these 3 megahabitat categories. We further constrained our model predictions to the depth range (50 to $860 \mathrm{~m}$ ) of dives in our dataset, and only interpolated predictions within the ranges of the model covariates as determined by standard error estimates $(\mathrm{SE}=10)$ of the predictions.

We described the biotic co-occurrences of Christmas tree corals, in the context of our final model covariates, by constructing NMS plots (Kruskal 1964, Mather 1976) implemented with PC-ORD software (McCune \& Mefford 2006) and overlaid with environmental gradient contours. We positioned individual samples by average Bray-Curtis dissimilarity dis- tances (Bray \& Curtis 1957) according to covariation and association among fish and invertebrate taxa. We began with a random initial starting configuration and determined the appropriate number of dimensions for the best ordination by examining stress versus dimension plots. We determined the best solution when the standard deviation in stress over the preceding 10 iterations reached $1 \times 10^{-5}$. Individual taxa were plotted in ordination space by calculating a weighted average for each taxon across all of the sites' scores. We performed an indirect gradient analysis of the relationship among taxa and model covariates, representing each habitat variable as a contour gradient overlaid on top of the previously constructed NMS ordination plot (Virtanen et al. 2006, Salemaa et al. 2008, Huff et al. 2011) using R software (Ihaka \& Gentleman 1996, Oksanen 2004). We constructed habitat variable contours with nonparametrically smoothed surfaces that were fitted from GAMs (Gaussian error distribution with identity link) with thin plate splines (Wood 2000). The degree of smoothing was determined using cross-validated $\mathrm{R}^{2}$ to determine goodness-of-fit. We tested the significance of each environmental gradient contour surface with an ANOVA.

\section{RESULTS}

\section{Coral observations}

Christmas tree corals were present at 27 of 60 transect groups. We observed corals at depths that ranged from 58 to $914 \mathrm{~m}$ and at densities from 1 colony per 10 transects $\left(0.003\right.$ colonies $\left.\mathrm{m}^{-2}\right)$ to 24 colonies per transect $\left(0.446\right.$ colonies $\left.\mathrm{m}^{-2}\right)$. Coral colonies were always attached to some hard substrate. Transect groups ranged from 1 to $100 \%$ hard substrate, and the median value for our observations was $63 \%$. Summary statistics for Christmas tree coral observations and model covariates for transects where corals were present are displayed in Table 1.

\section{Predicting coral density: GAM}

We examined boxplots of median and quartile monthly modeled velocities of bottom currents (both eastward and northward components) at locations where Christmas tree corals were present or absent and corresponding bar plots that indicate the strength of the current-coral relationship (Fig. 3). Bottom currents were weaker at locations where corals were 
Table 1. Antipathes dendrochristos. Summary statistics for Christmas tree coral observations and model covariates for transects where corals were present

\begin{tabular}{|c|c|c|c|c|c|c|}
\hline Statistic & Mean & SD & Minimum & Median & Maximum & Resolution \\
\hline Colonies per transect & 4.9 & 7.4 & 0.1 & 1.6 & 24.0 & Transect \\
\hline Coral colony height $(\mathrm{cm})$ & 47 & 52 & 10 & 30 & 262 & Transect \\
\hline Colonies $\mathrm{m}^{-2}$ & 0.061 & 0.081 & 0.003 & 0.026 & 0.446 & Transect \\
\hline Percent hard substrate & 57 & 30 & 1 & 63 & 100 & Transect \\
\hline Depth (m) & 228 & 153 & 58 & 183 & 914 & $90 \mathrm{~m}$ \\
\hline Temperature $\left({ }^{\circ} \mathrm{C}\right)$ & 8.0 & 1.2 & 4.9 & 8.4 & 9.6 & $0.125^{\circ}$ \\
\hline Chlorophyll persistence index & 17 & 2 & 13 & 17 & 20 & $0.125^{\circ}$ \\
\hline Northward current $\left(\mathrm{m} \mathrm{s}^{-1}\right)$ & 0.001 & 0.006 & -0.005 & 0.000 & 0.014 & $0.125^{\circ}$ \\
\hline Eastward current $\left(\mathrm{m} \mathrm{s}^{-1}\right)$ & -0.001 & 0.012 & -0.024 & 0.000 & 0.013 & $0.125^{\circ}$ \\
\hline
\end{tabular}
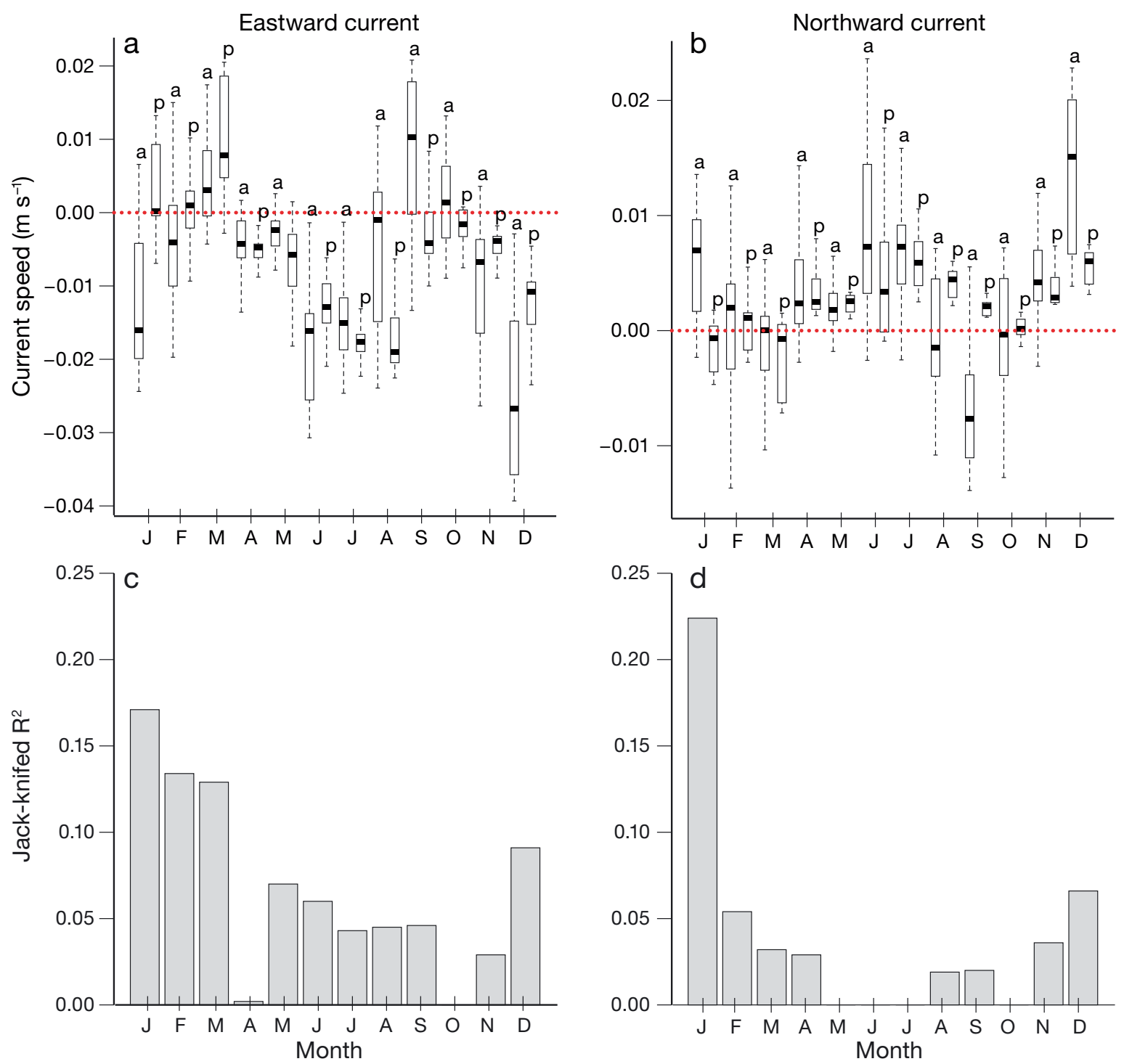

Fig. 3. Monthly (a) eastward and (b) northward bottom current velocities. Each monthly pair is labeled 'a,' indicating samples $(n=33)$ in the dataset where Christmas tree corals were absent and ' $\mathrm{p}$,' indicating samples $(\mathrm{n}=27)$ where Christmas tree corals were present each month. Black bar = median, box = quartiles, whiskers = range. $(\mathrm{c}, \mathrm{d})$ Bar-plots represent leave-one-out jack-knifed $\mathrm{R}^{2}$ values for the non-parametric regressions between Christmas tree coral quantity and current velocities for each month 
present than at locations where corals were absent. For both eastward and northward current components, the current-coral relationship was strongest in January ( $R^{2}=0.17$ and 0.23 , respectively), and median northward current velocity in January was near $0 \mathrm{~m}$ $\mathrm{s}^{-1}$ at locations where corals were present and $0.007 \mathrm{~m}$ $\mathrm{s}^{-1}$ where corals were absent. Modeled water temperatures at the seafloor were warmest during January (mean $\pm \mathrm{SE}=7.7 \pm 0.19^{\circ} \mathrm{C}$ ) when the coral-current relationship was strongest.

After we removed collinear covariates from the analysis, temperature, January northward current velocity (Jan North), CPI, and depth remained as candidates in the selection process for our model to predict coral density. A GAM that included Depth, Jan North, CPI, Temperature, and the interaction Depth $\times$ CPI ranked highest $\left(w_{i}=0.69\right)$ out of the 20 models that were constructed from all possible subsets of the candidate variables that included both main effects with an interaction present (Table 2). The final model accounted for $88.4 \%$ of the deviance in coral density and had a mean $\mathrm{R}^{2}=0.51$ for 500 runs of 10 -fold cross-validation.

The Depth response curves (Fig. 4a) indicated that there was a greater density (coral colonies per transect group area) of Christmas tree corals at higher (third quartile) CPI values across the same depth range than at lower (first quartile) CPI values. Midrange depths (300-500 m) had the highest modeled coral density. There was a deeper optimum depth range and greater coral density at high CPI values over the same depth values (Fig. 4a). The CPI

Table 2. Antipathes dendrochristos. Results of model selection examining environmental features that influence the density and size of Christmas tree corals in the Southern California Bight. Models are ranked by Akaike's information criterion (AIC) and Akaike weights $\left(w_{i}\right)$ with either quasi-AIC (coral density models; $\triangle$ QAIC) or corrected for small sample size (coral size models; $\Delta \mathrm{AIC}_{\mathrm{c}}$ ). Only the top sequential models representing nearly all of the weight for each response are included. Coral density was predicted with generalized additive models (GAMs) using a quasiPoisson error distribution and a log link. Coral size was predicted with general linear models (GLMs) using a Gaussian error distribution and log link. CPI: chlorophyll persistence index

\begin{tabular}{|lcc|}
\hline Model effects & $w_{i}$ & $\begin{array}{c}\Delta \mathrm{QAIC} \text { or } \\
\Delta \mathrm{AIC}_{\mathrm{C}}\end{array}$ \\
\hline Coral density (GAMs) & & \\
Depth + CPI + Depth×CPI + Jan North Current + Temperature & 0.69 & 0 \\
Depth + CPI + Jan North Current + Temperature & 0.26 & 1.9 \\
Depth + CPI + Depth×CPI + Temperature & 0.05 & 5.4 \\
& & \\
Coral size (GLMs) & & \\
Depth + CPI + Depth×CPI + Jan East Current + Temperature & 0.40 & 0 \\
Depth + CPI + Depth×CPI + Temperature & 0.22 & 1.2 \\
Depth + CPI + Jan East Current + Temperature & 0.15 & 2.0 \\
\hline
\end{tabular}

response curve indicated generally increasing coral quantity with greater values of CPI (Fig $4 \mathrm{~b}$ ). The Jan North velocity response curve was unimodal (Fig. 4c), centered around $0 \mathrm{~m} \mathrm{~s}^{-1}$ (northward), and was consistent with the coral-current relationships identified in Fig. 3. The Temperature response curve was unimodal with the greatest density of corals centered about $8.5^{\circ} \mathrm{C}$.

\section{Predicting coral size: GLM}

After we removed collinear covariates from the analysis, Temperature, January eastward current velocity (Jan East), August eastward current velocity (Aug East), CPI, and Depth remained as candidates in the selection process for a model to predict coral size. A GLM that included Depth, CPI, Jan East, Temperature, and the interaction Depth $\times$ CPI ranked highest $\left(w_{i}=0.40\right)$ out of the 40 models that were constructed from all possible subsets of the candidate variables (Table 1). The final model accounted for $89.8 \%$ of the deviance in the coral size dataset, with the greatest deviance reduction attributed to CPI and Depth (Table 3). The final GLM had a mean $\mathrm{R}^{2}=0.40$ for 500 runs of 5 -fold cross-validation.

The largest coral colonies were predicted at shallower depths (Fig. 5a), and coral size increased with eastward component of the current velocity in January increased (Fig. 5c), and coral size decreased with increasing mean temperatures (Fig. 5d). There was an increasing trend in coral size with increasing CPI over similar depths (Fig. 5a) and greater coral sizes at shallower depths (first quartile of depth) versus deeper depths (third quartile of depth) over similar CPI values (Fig. 5b).

\section{Mapping coral distribution and environmental covariates}

Areas within the Southern California Bight that have the highest predicted densities of Christmas tree corals also have relatively weak modeled current velocities during January (Fig. 6a). CPI values (Fig. 6b) 

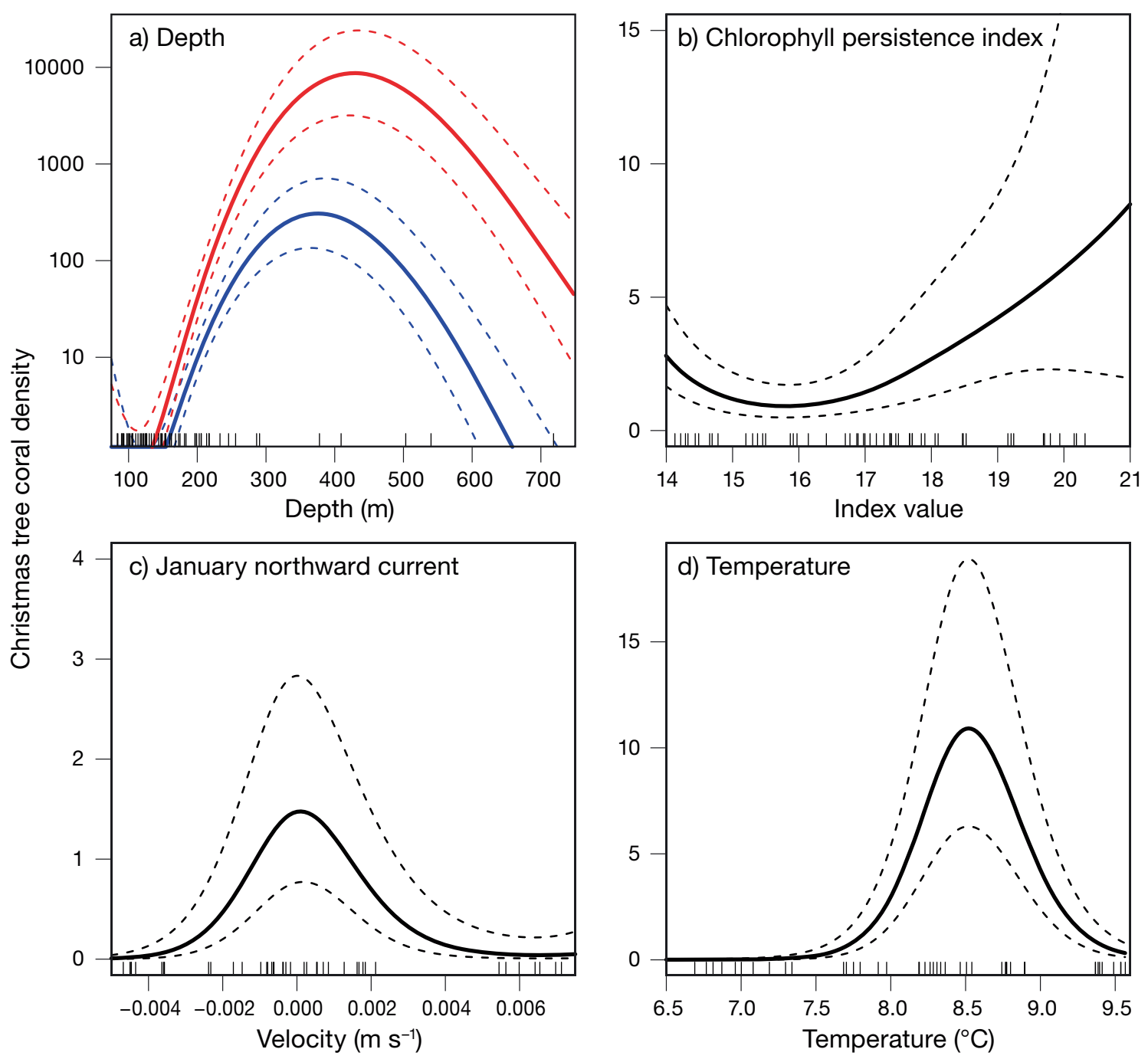

Fig. 4. Antipathes dendrochristos. Response curves for the generalized additive model-predicted density (coral colonies per transect group) of Christmas tree corals versus (a) depth, (b) chlorophyll persistence index (CPI), (c) January northward current, and (d) temperature. Solid lines represent the mean and dashed lines represent 1 SE from the mean. For (a) depth plots, velocity and temperature were held at the median value and curves are displayed for the first and third quartiles of CPI (15.3 [blue] and 17.9 [red], respectively). For the (b) CPI, (c) January northward current, and (d) temperature plots, all other covariates were held at median values. Rug plots along the $x$-axis indicate observed data points

Table 3. Antipathes dendrochristos. Analysis of deviance for the generalized linear model for size response of Christmas tree corals. Terms added sequentially in the order they occur in the table. CPI: chlorophyll persistence index; Jan East: January eastward current

\begin{tabular}{|lccc|}
\hline Model & $\begin{array}{c}\text { Deviance } \\
\text { reduction }\end{array}$ & $\begin{array}{c}\text { Residual } \\
\text { df }\end{array}$ & $\begin{array}{c}\text { Residual } \\
\text { deviance }\end{array}$ \\
\hline Null & & 24 & 64097 \\
CPI & 23633 & 23 & 40464 \\
Depth & 20907 & 22 & 19558 \\
Jan East & 3587 & 21 & 15971 \\
Temperature & 7720 & 20 & 8251 \\
Depth×CPI & 1734 & 19 & 6517 \\
\hline
\end{tabular}

were greatest in the northwest portion of the study area and decreased along a southward-inshore gradient throughout the Bight. There was a relatively uniform gradient of high-to-low seafloor temperature from inshore to offshore throughout the Bight (Fig. 6c). Relatively high densities (hotspots) of Christmas tree corals were predicted to occur on various banks throughout the Bight, but were more concentrated in the north and in several near-shore areas from Point Conception to San Diego. The most substantial predicted hotspots of coral density occurred on Piggy Bank and Footprint Seamounts and near Hidden Reef (Fig. 2). 

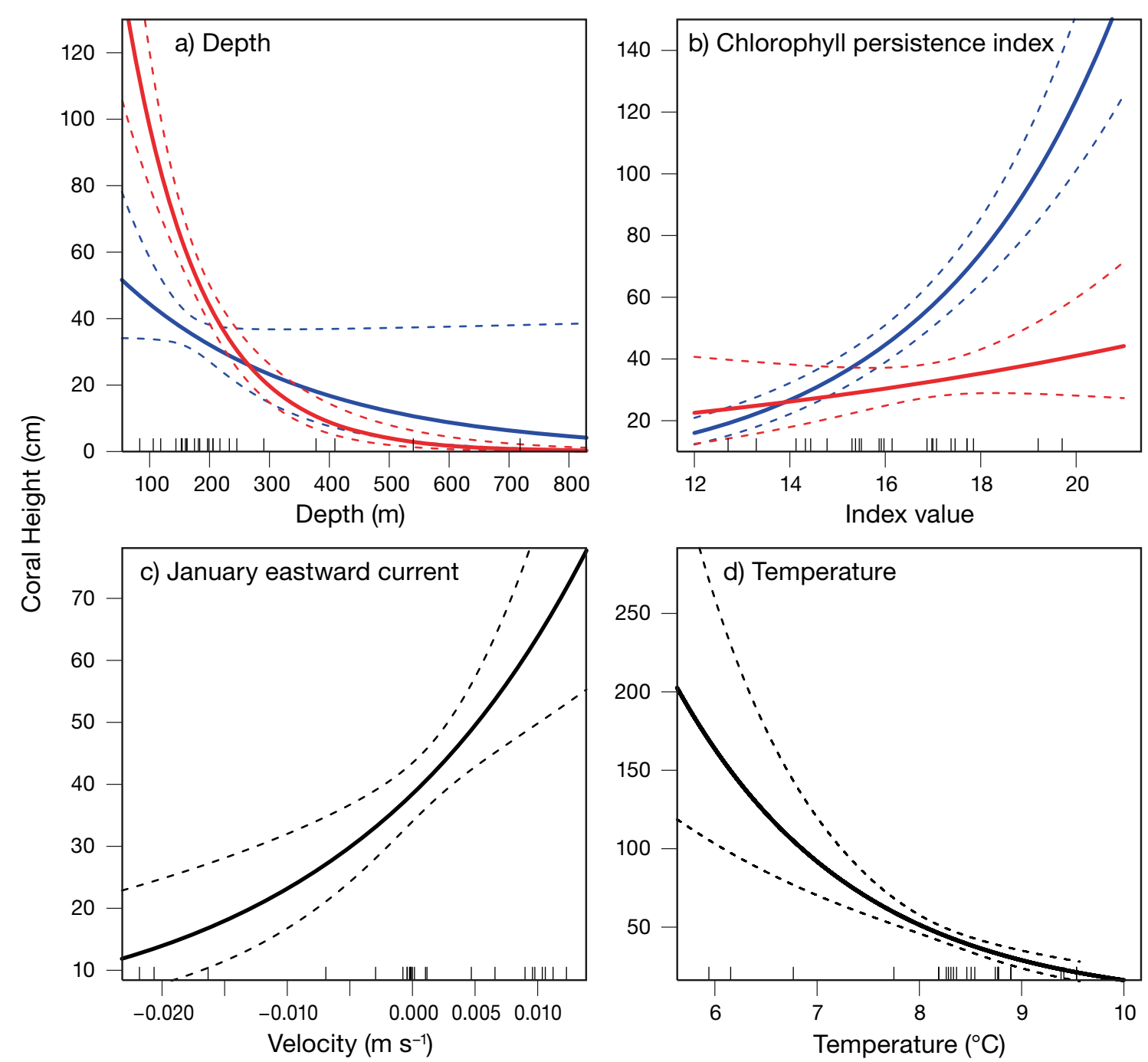

Fig. 5. Antipathes dendrochristos. Response curves for the generalized linear model-predicted size of Christmas tree corals versus (a) depth, (b) chlorophyll persistence index (CPI), (c) January eastward current, and (d) temperature. Solid lines represent the mean and dashed lines represent 1 SE from the mean. For (a) depth and (b) CPI plots, velocity and temperature were set at median values and curves are displayed for the first and third quartiles of CPI (15.3 [blue] and 17.9 [red], respectively) for the depth response curve, and depth (112 m [blue] and $204 \mathrm{~m}$ [red], respectively) for the CPI response curve. For (c) January eastward current and (d) temperature, all other covariates were set at median values. Rug plots along the $x$-axis indicate calibration data points

An independent data set (from the National Ocean Service and the National Marine Fisheries Service Southwest Fisheries Science Center) of the presence and absence of Christmas tree corals validated the major coral hotspots predicted by the coral density model. We grouped independent validation data into 15 samples by location and depth, in the same way that our model calibration data were grouped, and made predictions for the sample locations. Thirteen out of 15 of the presence records in the validation dataset coincided with model predictions $>1$ coral colony per transect $\left(740 \mathrm{~m}^{2}\right)$. The predictive capabil- ity of our model declined in the southern offshore areas where we did not survey. In the independent validation data set, 2 Christmas tree corals occurred in the southern offshore areas but were predicted to occur at $<1$ coral colony per $740 \mathrm{~m}^{2}$.

\section{Biotic associations}

Based on the results from our NMS analysis, the relationship of Christmas tree coral colonies to 85 fish and other invertebrate taxa from 47 transect groups 


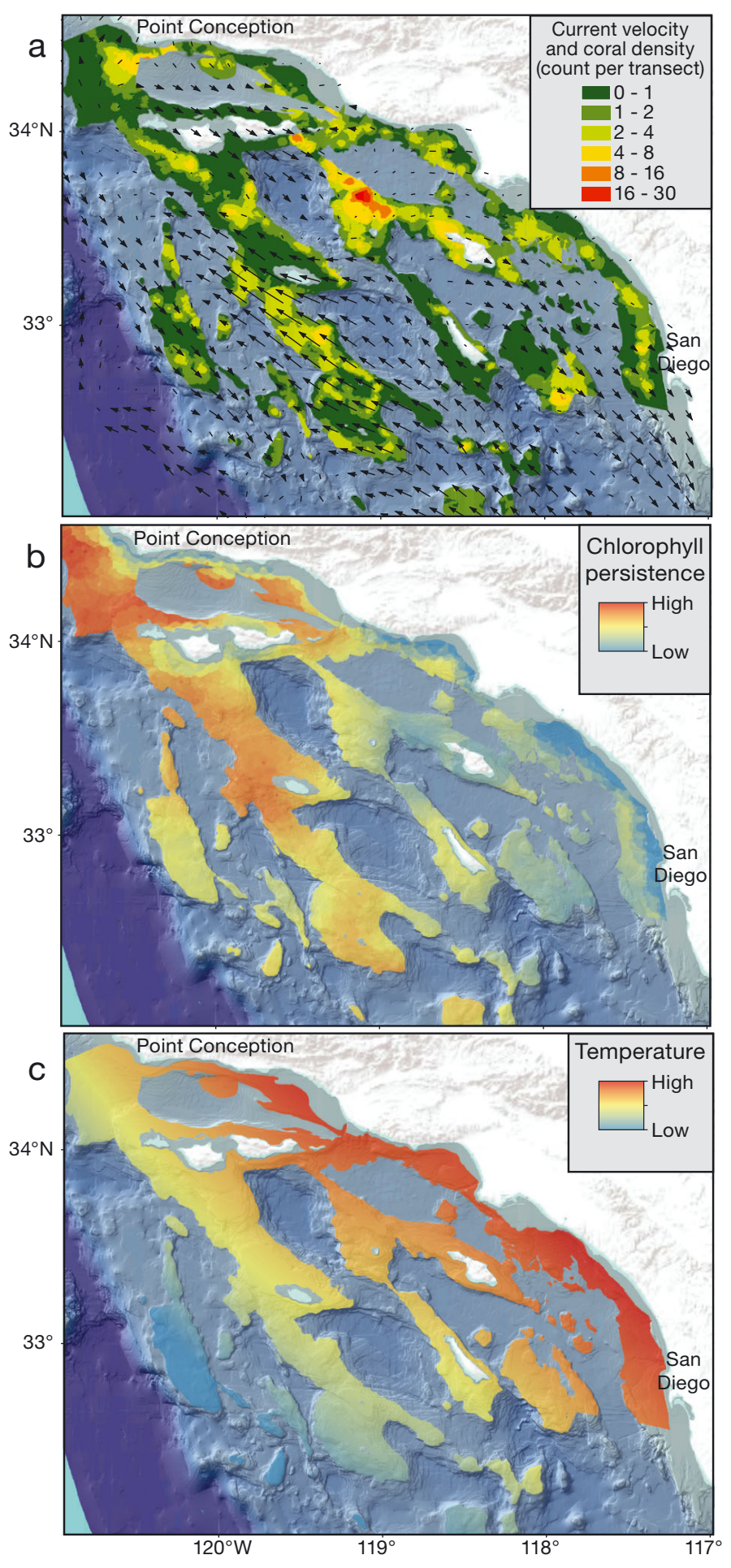

Fig. 6. Antipathes dendrochristos. Spatial distribution of model covariates and the predicted density (coral count per transect) of Christmas tree corals throughout the Southern California Bight. (a) Arrows represent the magnitude and direction of modeled current velocity near the seafloor in January (min. = $0 \mathrm{~m} \mathrm{~s}^{-1}$, max. $=0.3 \mathrm{~m} \mathrm{~s}^{-1}$ ), (b) predicted chlorophyll persistence index $(\min .=2.4$, $\max .=24.4)$, $(\mathrm{c})$ predicted seafloor temperature $\left(\min .=1.9^{\circ} \mathrm{C}, \max .=10.0^{\circ} \mathrm{C}\right)$ was described in the context of the final GAM covariates and the proportion of hard substratum per sample unit (Appendix 1). We chose a 2-dimensional solution for the NMS plot by examining scree plots, and Monte Carlo runs resulted in a p-value of 0.004 , suggesting that the final stress value had a low probability of random occurrence (McCune et al. 2002). Stress for the final solution was 14 (after 83 iterations). The proportion of variance represented by 2 axes between the original distance matrix and the ordination distances was $\mathrm{R}^{2}=0.75$, and the orthogonality [100(1- $R^{2}$ of axis pair)] of axes 1 and 2 was $99.2 \%$.

Benthic assemblage structure varied extensively over the environmental gradients. Weighted-average NMS scores for 47 representative taxa (out of 85) were plotted in the original sample ordination space (Fig. 7). Christmas tree corals were positioned centrally in the NMS plots relative to the other taxa and occurred at the approximate median of the environmental gradients. In general, fish and invertebrate taxa separated along the horizontal axis in each covariate plot. The distribution of Christmas tree corals was centered at $250 \mathrm{~m}$ depth (Fig. 7a), along with a variety of rockfishes (e.g. greenblotched and bronzespotted) and sponges (e.g. barrel and branching). Christmas tree corals were associated with relatively high proportions of hard substratum (70-80\%; Fig. 7b), but not as strongly as many sponge taxa were (e.g. foliose, shelf, and branching sponges occurred in samples with $90 \%$ hard substratum). Fewer taxa occurred in samples with relatively low proportions of hard substratum. The CPI gradient (Fig. 7c) was approximately orthogonal with the depth gradient (Fig. 7a), and greater CPI values were associated with benthic invertebrates rather than fish taxa (particularly at deeper depths). Christmas tree corals were situated near the 0 velocity of the northward seafloor current in January (Fig. 7d), in accordance with results from the best coral density GAM.

\section{DISCUSSION}

Our analysis revealed that ocean currents and regions of relatively high surface primary productivity, especially in combination with depth, are important predictors of Christmas tree coral density. We included the CPI covariate to represent a coarse proxy for the amount of food (organic material) available to benthic organisms over a large temporal scale because the abundance and size of these long-lived corals may reflect climate-driven patterns in their 
a) Depth (m)

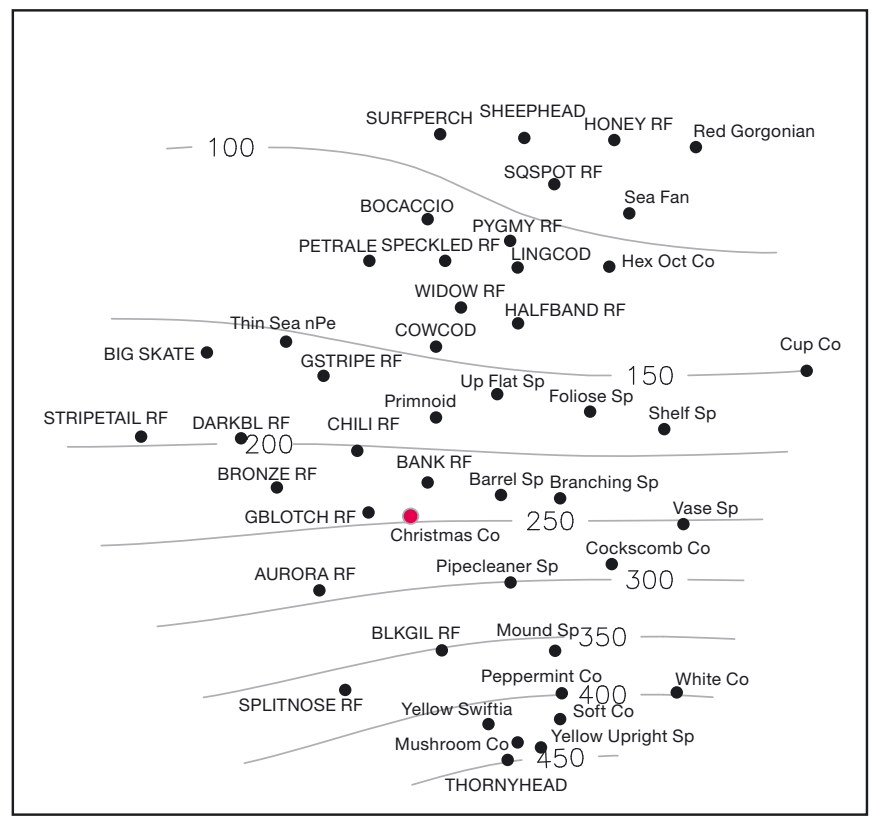

c) Chlorophyll persistence index

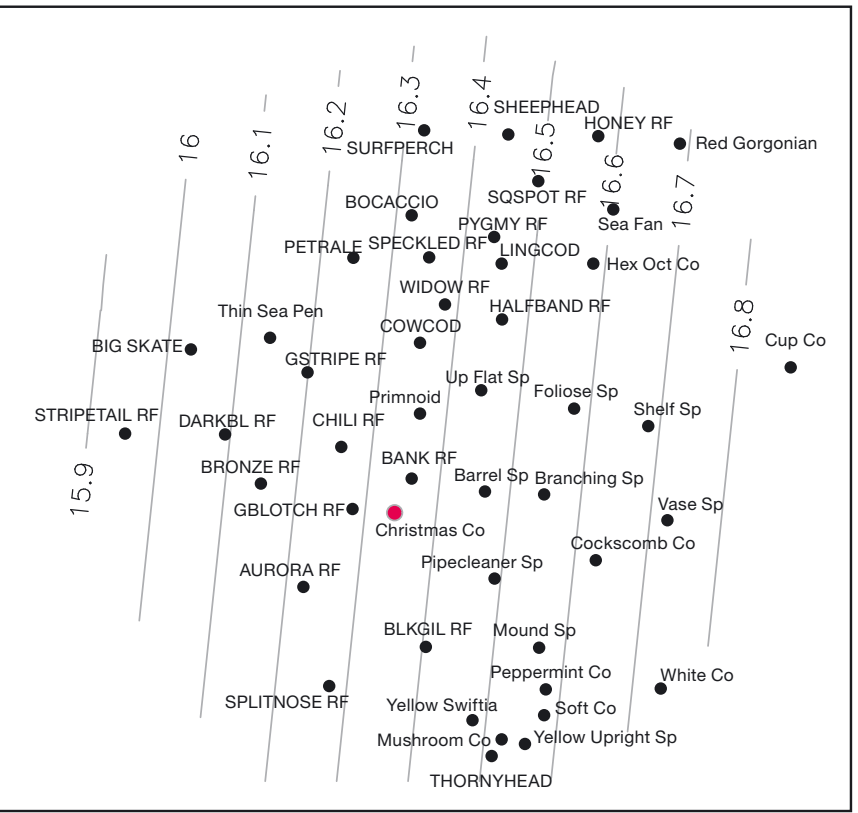

b) Percent hard substratum

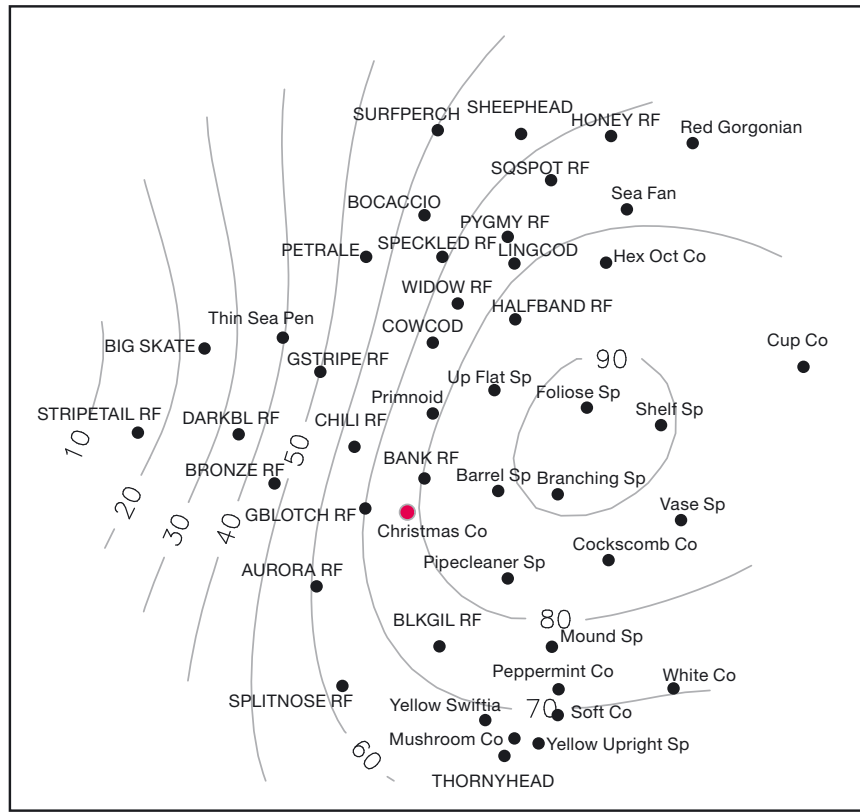

d) January northward current $\left(\mathrm{m} \mathrm{s}^{-1}\right)$

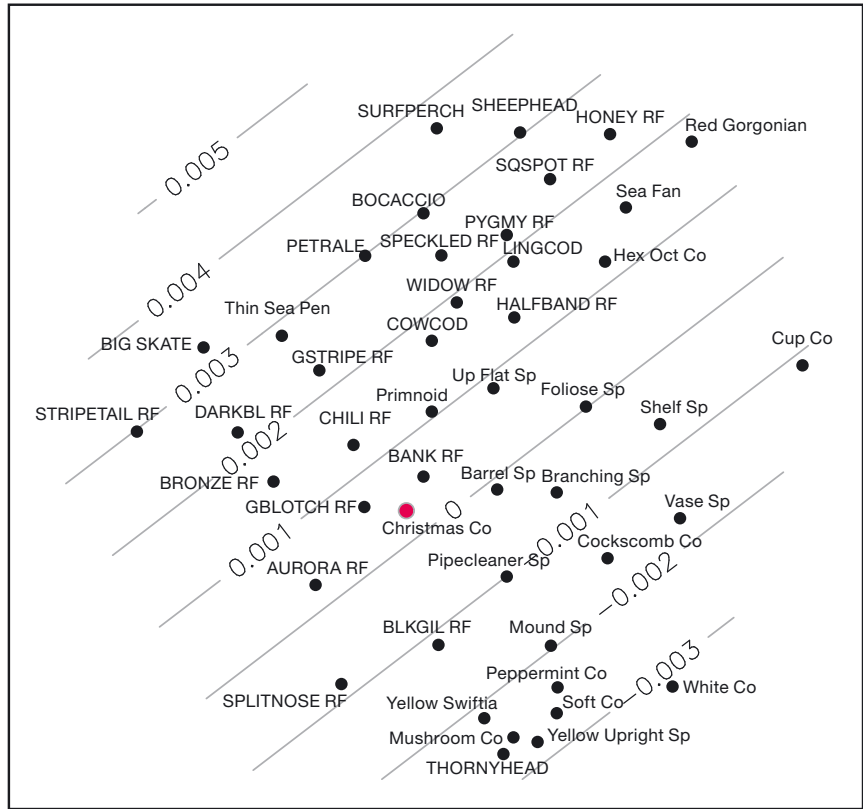

Fig. 7. Non-metric multidimensional scaling plots based on the Bray-Curtis distances among sample transects. Each panel contains the identical taxon constellation (Christmas tree coral depicted in red) with a different fitted contour surface for covariates in the coral density GAM: (a) depth, (b) percent hard substratum (rock, pinnacle, flat rock, boulder, and cobble) per transect, (c) chlorophyll persistence index, and (d) January northward current. Only 47 of 85 taxa are displayed to improve the readability of the plots; the complete list of taxa is available in Appendix 1

food supply (Smith et al. 1994, Ruhl \& Smith 2004, Suryan et al. 2012). The cold-water coral Lophelia pertusa subsists on phytoplankton delivered from primary productivity near the surface (Duineveld et al. 2004, 2007, 2012), and phytoplankton and detritus may be consumed by antipatharians as well (Wagner et al. 2012). The modeled interaction of CPI with depth supports our hypothesis that areas with persistent levels of surface productivity have a more tenuous connection to benthic organisms (e.g. Christmas tree corals) at greater depths than those closer to the surface. Depth, by itself, may act as a surrogate for 
any number of other correlated factors that have physiological consequences, such as temperature, oxygen, salinity, and aragonite or calcite saturation. However, depth is easily measured, and such data may be more reliably accurate and available than those of other modeled habitat features. Finally, seafloor currents at the scale of our oceanographic model were hypothesized to affect corals by 2 general mechanisms that we discuss in detail below: food transport and larval dispersal.

Seafloor currents may be important for supplying food to cold-water corals (Frederiksen et al. 1992, Druffel et al. 1995, Davies et al. 2009). Topographic relief can accelerate currents, thereby improving particle supply to corals (Genin et al. 1986, Thiem et al. 2006). This mechanism would deliver organic particles that are re-suspended by turbulence and then transported by advection. However, particles near the seafloor may contain fewer usable labile organic compounds as a result of microbial activity in the benthic boundary (Ritzrau et al. 1997). An alternative explanation to the particle supply hypothesis for finescale positioning of cold-water corals lies in the requirement of most corals for a hard substrate attachment; following larval settlement, suspended sediments and organic particles may settle and smother small, developing corals (White et al. 2005). There is evidence that breaking internal waves may deliver food to cold-water corals either by redistributing particles in the bottom mixed layer or by increasing vertical nutrient flux, which promotes surface productivity (Frederiksen et al. 1992). Davies et al. (2009) suggested that the food supply for the coldwater coral Lophelia pertusa in the North Atlantic Ocean originated outside the reef area through an interaction among tides, rapidly down-welled surface water, and topography. Our oceanographic circulation model may reflect current patterns that are correlated with a food supply arriving more directly from surface layers. It also is feasible that our CPI values are associated with complex food delivery mechanisms, and that coarse covariate resolution $\left(0.125^{\circ}\right)$ benefits the coral model function because there may be significant lateral advection of organic particles from the surface to the benthos (Smith \& Kaufmann 1999).

Although Christmas tree coral reproductive traits have not been documented, black corals tend to be gonochoric and fertilization likely occurs externally (Wagner et al. 2011, 2012). Studies also suggest that spawning is synchronous and tied to seasonal cycles in food input, although tidal or annual temperature cycles may be more important in less seasonal areas
(Gooday 2002, Gori et al. 2007, Roberts et al. 2009). For relatively shallow black corals, the reproductive cycle appears to be periodic, and gamete maturity coincides with periods of higher water temperatures (Parker et al. 1997, Wagner et al. 2011). Very little is known about the larval biology of black corals; currently larval behavior has been observed only in laboratory cultures of Antipathella fiordensis (Miller 1996). These larvae were weak swimmers, negatively buoyant, and lived a maximum of $10 \mathrm{~d}$. In another study of this species, fine-scale patterns of relatedness suggested that dispersal of black coral larvae is highly philopatric with settlement very close to parental colonies (Miller 1998). The scale of larval dispersal may be highly variable and is likely to be associated with bottom current velocity (Richards et al. 1995, Miller 1998) and micro-scale flow, which may affect larval supply to high-relief, rugose areas (Willis \& Oliver 1990, Graham \& Sebens 1996). The importance of the January bottom currents in our models is consistent with the hypothesis that restricted larval dispersal is an adaptation to deep-sea environments in which Christmas tree corals live on isolated, rocky outcrops. Modeled January water temperatures from our study were the warmest temperatures of the year. If spawning occurs during the warmest months, as previous research on closely related species indicates, then locations with weak bottom currents would be more likely to retain larvae and decrease the likelihood of larvae being dispersed away from suitable habitat or becoming isolated from conspecifics. Our finding that areas within the Bight that are associated with weak bottom currents in January are predicted to have the greatest density of coral colonies provides support for this hypothesized mechanism.

Models that incorporate both the growth and survival of individuals may provide a more accurate determination of suitable coral habitat (Stoner 2003). Our GLM of predicted coral size incorporated CPI, January eastward current, depth, the interaction of depth and CPI, and temperature. This finding, using an alternative response and a subset of the data, was in accord with the results of our GAM of predicted coral densities and adds credence to our inference that modeled oceanographic factors associated with growth and reproduction may explain a substantial portion of the variance in coral distribution. Greater CPI values were associated with larger coral, which supports the inference that greater surface productivity improves coral habitat suitability in the Southern California Bight. Because there are fewer size data, the nature of the depth-CPI interaction in the 
GLM model is less clear than in the GAM results. There was a trend of larger corals across similar shallow depths with increasing CPI, but there were few data on size of colonies at deep water depths and low CPI values, so an analogous relationship to coral density and CPI is more difficult to discern. Temperature has been shown to be an important determinant of coral distribution (Roberts et al. 2009), and mean temperatures in our GLM indicated smaller coral colonies in warmer water, despite the trend of larger coral colonies occurring in shallower water. It may be that larger, shallow corals benefit from localized upwelling which may result in both colder temperatures and increased primary productivity. In contrast, predicted coral density was greatest at relatively warmer temperatures in our data set. Because temperature is strongly collinear with salinity and dissolved oxygen, the interpretation of this response is ambiguous since it may be affected by the other collinear covariates as well.

Modeled oceanographic data have shown promise for predicting the distribution of marine species by characterizing important habitat features across broad regions (Huff et al. 2012). We chose to focus on specific mechanisms of interest and considered relevant covariates based on our knowledge of ocean conditions in the Southern California Bight and the availability of consistent oceanographic model output. We felt that Christmas tree corals at our study scale were less likely to be affected by minimum calcite saturation state or aragonite saturation horizon, which were important in large-scale or global coral models, because Christmas tree corals are noncalcified corals that occur at relatively shallow depths (Guinotte et al. 2006, Davies et al. 2008, Yesson et al. 2012).

Predictive modeling holds great potential to improve our understanding of the ecological niche occupied by cold-water corals, although our ability to predict suitable habitat is limited by the resolution and availability of relevant environmental data and by a lack of knowledge regarding their life histories. A significant limitation in developing models to predict the distribution and abundance of cold-water corals is the lack of high-resolution spatial data on seafloor depth and substrate type. Fine-scale physical features and topographical characteristics are important determinants of deep-water coral distributions (Stone 2006, Woodby et al. 2009). Globally, only 5 to $10 \%$ of the seafloor is currently mapped at a useful resolution to study the importance of detailed landscape configuration for the distribution of coldwater corals (Wright \& Heyman 2008). High-resolu- tion mapping of about $75000 \mathrm{~km}^{2}$ of the seafloor to a depth of $1300 \mathrm{~m}$ is still needed off California. Coldwater coral habitats incorporate a complex set of interactions among oceanography, food supply, and suitable substrata. Broad-scale geographic information on substratum types in our study was limited to megahabitat features on a spatial scale of 100 to $1000 \mathrm{~m}$. Given the unconditional necessity of rocky substrata for the presence of Christmas tree corals, the acquisition of Bight-wide high-resolution spatial data on substratum types is required in order to improve the predictive performance of habitat-based coral models.

Both the GAM and GLM described a high proportion of the variance in the data using penalized loglikelihood methods and generalized cross-validation to avoid model over-fitting. Nonetheless, model predictions may function quite well with training data (or a subset of it), but then perform poorly with data from an independent set of validation sites. By using validation data from the same samples as our calibration dataset, our $k$-fold cross-validation process was moderately rigorous. Our models provided realistic estimates of predictive performance; our GAM accounted for $51 \%$ of the variance in coral density, and our GLM accounted for $40 \%$ of the variance in coral colony size. The independent dataset contained presence records that were obtained using a different survey methodology and that have covariates outside the range of our modeled calibration data. However, these independent data provided a qualitative assessment of the strengths and weaknesses in the predictive power of our density model, including agreement with model predictions comparable to our cross-validation results. As expected, model performance was poorest in areas with no calibration data (primarily in the southern portion of the Bight). Collecting information on coral densities and size composition in these areas remains a priority.

Christmas tree corals could indicate habitat potential for the broader associated community and could be a useful proxy for worthwhile habitats to protect. From our NMS plots, the relative position of Christmas tree corals in the community was defined in the context of factors that were included in our selected GAM and GLM models (e.g. productivity, depth, current strength) or known to be important to these corals (i.e. available rocky substrata). Gradient maps such as these may be used to compare habitat requirements of different taxa, and to identify patterns for future ecological investigations or conservation planning. In our dataset, Christmas tree corals occupy a relatively central position in the community 
and are widely distributed across the gradients. The complex 3-dimensional architecture of Christmas tree corals and conditions in which they occur provide a variety of niches for many members of this benthic community. Mobile organisms, such as fish, may hide among their branches but not be obligate associates with black corals (Tissot et al. 2006). Many organisms, such as crinoids, basket stars, and brittle stars, occupy the dead branches and trunks of these corals (Love et al. 2007). Although there may not be clear evidence that fish and invertebrates depend on Christmas tree corals, these species co-occur in areas with similar habitat features (Tissot et al. 2006).

Some areas of predicted high densities of Christmas tree corals in the Southern California Bight are located inside marine protected areas where bottomfishing gear has been prohibited (Fig. 2). However, there are several predicted hotspots of these corals that remain unprotected from fishing activities, particularly in areas adjacent to Point Conception and the most populated portions of the Bight near the ports of Los Angeles, Long Beach, and San Diego. Relatively little is known about the occurrence of Christmas tree corals and other coral species in these unprotected rocky areas, and yet numerous potential stressors (e.g. water pollution, marine debris, sustained fishing) have prevailed for decades in coastal waters within $20 \mathrm{~km}$ of the greater Los Angeles-San Diego metropolitan area. A great deal could be learned about the resiliency of these cold-water corals by assessing their abundance, diversity, and health in unprotected areas and making comparisons with those afforded protection from fishing and other impacts.

Acknowledgements. We thank 3 anonymous reviewers and the associate editor for detailed suggestions and comments on the manuscript. We greatly appreciate the capable assistance of T. Laidig, A. Taylor, and M. Nishimoto in analyzing the visual surveys. Helpful comments on earlier drafts of this manuscript were provided by T. Hourigan, P. Etnoyer, and T. Laidig. We thank K. Stierhoff and P. Etnoyer for supplying the independent validation data set and Fig. 1. Supplemental funds were provided through grants to M.M.Y. from the NMFS Office of Habitat Conservation Deep Sea Coral Research and Technology Program.

\section{LITERATURE CITED}

Austin MP (2002) Spatial prediction of species distribution: an interface between ecological theory and statistical modelling. Ecol Model 157:101-118

Barnett AM, Jahn AE (1987) Pattern and persistence of a nearshore planktonic ecosystem off Southern California. Cont Shelf Res 7:1-25
Bartoń K (2011) MuMl package: multi-model inference. Available at www.cran.r-project.org/web/packages

Bidigare RR, Chai F, Landry MR, Lukas R and others (2009) Subtropical ocean ecosystem structure changes forced by North Pacific climate variations. J Plankton Res 31: 1131-1139

Bivand R, Altman M, Anselin L, Assuno R and others (2012) spdep: Spatial dependence: weighting schemes, statistics and models. Available at www.cran.r-project.org/ web/packages

Bo M, Tazioli S, Spano N, Bavestrello G (2008) Antipathella subpinnata (Antipatharia, Myriopathidae) in Italian seas. Ital J Zool 75:185-195

Bo M, Lavorato A, Di Camillo CG, Poliseno A and others (2012) Black coral assemblages from Machalilla National Park (Ecuador). Pac Sci 66:63-81

$>$ Bray JR, Curtis JT (1957) An ordination of the upland forest communities in southern Wisconsin. Ecol Monogr 27: 325-349

$>$ Bryan TL, Metaxas A (2007) Predicting suitable habitat for deep-water gorgonian corals on the Atlantic and Pacific Continental Margins of North America. Mar Ecol Prog Ser 330:113-126

Chai F, Dugdale RC, Peng TH, Wilkerson FP, Barber RT (2002) One-dimensional ecosystem model of the equatorial Pacific upwelling system. Part I: model development and silicon and nitrogen cycle. Deep-Sea Res II 49: 2713-2745

Chai F, Liu GM, Xue HJ, Shi L and others (2009) Seasonal and interannual variability of carbon cycle in South China Sea: a three-dimensional physical-biogeochemical modeling study. J Oceanogr 65:703-720

Chambers JM, Hastie T (1993) Statistical models in S. Chapman \& Hall, New York, NY

Childress JJ, Seibel BA (1998) Life at stable low oxygen levels: adaptations of animals to oceanic oxygen minimum layers. J Exp Biol 201:1223-1232

Clark M, Tittensor D, Rogers A, Brewin P and others (2006) Seamounts, deep-sea corals and fisheries: vulnerability of deep-sea corals to fishing on seamounts beyond areas of national jurisdiction. UNEP-WCMC, Cambridge

> Crowder LB, Osherenko G, Young OR, Airame S and others (2006) Sustainability - resolving mismatches in US ocean governance. Science 313:617-618

Dailey MD, Reish DJ, Anderson JW (1993) Ecology of the Southern California Bight: a synthesis and interpretation. University of California Press, Berkeley, CA

> Davies AJ, Guinotte JM (2011) Global habitat suitability for framework-forming cold-water corals. PLoS ONE 6: e18483

> Davies AJ, Wisshak M, Orr JC, Roberts JM (2008) Predicting suitable habitat for the cold-water coral Lophelia pertusa (Scleractinia). Deep-Sea Res I 55:1048-1062

Davies AJ, Duineveld GCA, Lavaleye MSS, Bergman MJN, van Haren H, Roberts JM (2009) Downwelling and deepwater bottom currents as food supply mechanisms to the cold-water coral Lophelia pertusa (Scleractinia) at the Mingulay Reef complex. Limnol Oceanogr 54:620-629

Dormann CF, Elith J, Bacher S, Buchmann C and others (2013) Collinearity: a review of methods to deal with it and a simulation study evaluating their performance. Ecography 36:027-046

Druffel ERM, Griffin S, Witter A, Nelson E, Southon J, Kashgarian M, Vogel J (1995) Gerardia: bristlecone pine of the deep-sea? Geochim Cosmochim Acta 59:5031-5036 
Duineveld GCA, Lavaleye MSS, Berghuis EM (2004) Particle flux and food supply to a seamount cold-water coral community (Galicia Bank, NW Spain). Mar Ecol Prog Ser 277:13-23

Duineveld GCA, Lavaleye MSS, Bergman MJN, de Stigter H, Mienis F (2007) Trophic structure of a cold-water coral mound community (Rockall Bank, NE Atlantic) in relation to the near-bottom particle supply and current regime. Bull Mar Sci 81:449-467

Duineveld GCA, Jeffreys RM, Lavaleye MSS, Davies AJ, Bergman MJN, Watmough T, Witbaard R (2012) Spatial and tidal variation in food supply to shallow cold-water coral reefs of the Mingulay Reef complex (Outer Hebrides, Scotland). Mar Ecol Prog Ser 444:97-115

Eakins BW (2003) U.S. Coastal relief model-Central Pacific. Available at www.ngdc.noaa.gov/mgg/coastal/ grddas07/grddas07.htm (accessed 15 April 2012)

Eppley RW (1992) Chlorophyll, photosynthesis and new production in the Southern California Bight. Prog Oceanogr 30:117-150

Frederiksen R, Jensen A, Westerberg H (1992) The distribution of the scleractinian coral Lophelia pertusa around the Faroe Islands and the relation to internal tidal mixing. Sarsia 77:157-171

> Genin A, Dayton PK, Lonsdale PF, Spiess FN (1986) Corals on seamount peaks provide evidence of current acceleration over deep-sea topography. Nature 322:59-61

Godambe VP, Heyde CC (1987) Quasi-likelihood and optimal estimation. Int Stat Rev 55:231-244

Gooday AJ (2002) Biological responses to seasonally varying fluxes of organic matter to the ocean floor: a review. J Oceanogr 58:305-332

Gori A, Linares C, Rossi S, Coma R, Gili JM (2007) Spatial variability in reproductive cycle of the gorgonians Paramuricea clavata and Eunicella singularis (Anthozoa, Octocorallia) in the Western Mediterranean Sea. Mar Biol 151:1571-1584

Graham KR, Sebens KP (1996) The distribution of marine invertebrate larvae near vertical surfaces in the rocky subtidal zone. Ecology 77:933-949

> Greene HG, Yoklavich MM, Starr RM, O'Connell VM and others (1999) A classification scheme for deep seafloor habitats. Oceanol Acta 22:663-678

Greene HG, Bizzarro JJ, Erdey DM, Lopez H, Murai L, Watt S, Tilden J (2003) Essential fish habitat characterization and mapping of California continental margin. Technical Publication Series. Moss Landing Marine Laboratories, Moss Landing, CA

Greene HG, Bizzaro JJ, O'Connell VM, Brylinsky CK (2007) Construction of digital potential marine benthic habitat maps using a coded classification scheme and its application. In: Todd BJ, Greene HG (eds) Mapping the seafloor for habitat characterization. Geological Association of Canada, St. John's, NL, p 141-155

Guinotte JM, Orr J, Cairns S, Freiwald A, Morgan L, George $R$ (2006) Will human-induced changes in seawater chemistry alter the distribution of deep-sea scleractinian corals? Front Ecol Environ 4:141-146

> Guisan A, Zimmermann NE (2000) Predictive habitat distribution models in ecology. Ecol Modell 135:147-186

Halpern BS, Walbridge S, Selkoe KA, Kappel CV and others (2008) A global map of human impact on marine ecosystems. Science 319:948-952

Hastie TJ, Tibshirani RJ (1990) Generalized additive models. Chapman and Hall, London

Hastie T, Tibshirani R, Friedman JH (2009) The elements of statistical learning: data mining, inference, and predic- tion. Springer series in statistics. Springer, New York, NY

Hickey BM (1992) Circulation over the Santa-Monica SanPedro Basin and Shelf. Prog Oceanogr 30:37-115

> Huff DD, Lindley ST, Rankin PS, Mora EA (2011) Green sturgeon physical habitat use in the coastal Pacific Ocean. PLoS ONE 6:e25156

> Huff DD, Lindley ST, Wells BK, Chai F (2012) Green sturgeon distribution in the Pacific Ocean estimated from modeled oceanographic features and migration behavior. PLoS ONE 7:e45852

Husby DM, Nelson CS (1982) Turbulence and vertical stability in the California Current. Calif Coop Ocean Fish Invest Rep 23:113-129

Ihaka R, Gentleman R (1996) R: a language for data analysis and graphics. J Comput Graph Statist 5:239-314

Klitgaard AB, Tendal OS, Westerberg H (1997) Mass occurrences of large sponges (Porifera) in Faroe Island (NE Atlantic) shelf and slope areas: characteristics, distribution and possible causes. In: Hawkins LE, Hutchinson S, Jensen AC, Sheader M, Williams JA (eds) The responses of marine organisms to their environments. Proc 30th Eur Mar Biol Symp. University of Southhampton, Southhampton, p 129-142

> Kruskal JB (1964) Multidimensional scaling by optimizing goodness of fit to a nonmetric hypothesis. Psychometrika 29:1-27

> Liu G, Chai F (2009) Seasonal and interannual variability of primary and export production in the South China Sea: a three-dimensional physical-biogeochemical model study. ICES J Mar Sci 66:420-431

Love MS, Yoklavich MM, Black BA, Andrews AH (2007) Age of black coral (Antipathes dendrochristos) colonies, with notes on associated invertebrate species. Bull Mar Sci 80:391-399

Love M, Yoklavich M, Schroeder D (2009) Demersal fish assemblages in the Southern California Bight based on visual surveys in deep water. Environ Biol Fishes 84: 55-68

Lundsten L, Barry JP, Cailliet GM, Clague DA, DeVogelaere AP, Geller JB (2009) Benthic invertebrate communities on three seamounts off southern and central California, USA. Mar Ecol Prog Ser 374:23-32

Maechler M, Rousseeuw P, Struyf A, Hubert M, Hornik K (2012) Cluster: cluster analysis basics and extensions. Available at www.cran.r-project.org/web/packages

Manderson J, Palamara L, Kohut J, Oliver MJ (2011) Ocean observatory data are useful for regional habitat modeling of species with different vertical habitat preferences. Mar Ecol Prog Ser 438:1-17

Mather PM (1976) Computational methods of multivariate analysis in physical geography. John Wiley and Sons, London

McCune B, Mefford MJ (2006) PC-ORD. Multivariate analysis of ecological data. MJM Software Design, Gleneden Beach, OR

McCune B, Grace JB, Urban DL (2002) Analysis of ecological communities. MJM Software Design, Gleneden Beach, OR

Miller K (1996) Piecing together the reproductive habits of New Zealand's endemic black corals. Water Atmos 4: 18-19

Miller KJ (1998) Short-distance dispersal of black coral larvae: inference from spatial analysis of colony genotypes. Mar Ecol Prog Ser 163:225-233

Moser GH, Smith PE (1993) Larval fish assemblages of the California Current region and their horizontal and vertical distributions across a front. Bull Mar Sci 53:645-691 
Mullin MM (1986) Spatial and temporal scales and patterns. In: Eppley RW (ed) Plankton dynamics of the Southern California Bight. Springer Verlag, Berlin, p 216-273

Oksanen J, Blanchet FG, Kindt R, Legendre P and others (2013) vegan: Community Ecology Package. R package version 2.0-9. R. CRAN

Opresko DM (2005) A new species of antipatharian coral (Cnidaria: Anthozoa: Antipatharia) from the Southern California Bight. Zootaxa 852:1-10

Parker NR, Mladenov PV, Grange KR (1997) Reproductive biology of the antipatharian black coral Antipathes fiordensis in Doubtful Sound, Fiordland, New Zealand. Mar Biol 130:11-22

Pikitch EK, Santora C, Babcock EA, Bakun A and others (2004) Ecosystem-based fishery management. Science 305:346-347

Polovina JJ, Chai F, Howell EA, Kobayashi DR, Shi L, Chao Y (2008) Ecosystem dynamics at a productivity gradient: a study of the lower trophic dynamics around the northern atolls in the Hawaiian Archipelago. Prog Oceanogr $77: 217-224$

Richards SA, Possingham HP, Noye BJ (1995) Larval dispersion along a straight coast with tidal currents: complex distribution patterns from a simple model. Mar Ecol Prog Ser 122:59-71

Ritzrau W, Thomsen L, Lara RJ, Graf G (1997) Enhanced microbial utilisation of dissolved amino acids indicates rapid modification of organic matter in the benthic boundary layer. Mar Ecol Prog Ser 156:43-50

Roberts JM, Wheeler A, Freiwald A, Cairns S (2009) Coldwater corals: the biology and geology of deep-sea coral habitats. Cambridge University Press, Cambridge

Ruhl HA, Smith KL (2004) Shifts in deep-sea community structure linked to climate and food supply. Science 305: 513-515

Salemaa M, Derome J, Nojd P (2008) Response of boreal forest vegetation to the fertility status of the organic layer along a climatic gradient. Boreal Environ Res 13:48-66

Scheltema RS (1986) On dispersal and planktonic larvae of benthic invertebrates - an eclectic overview and summary of problems. Bull Mar Sci 39:290-322

Shchepetkin AF, McWilliams JC (2005) The regional oceanic modeling system (ROMS): a split-explicit, free-surface, topography-following-coordinate oceanic model. Ocean Model 9:347-404

Sherwood OA, Heikoop JM, Scott DB, Risk MJ, Guilderson TP, McKinney RA (2005) Stable isotopic composition of deep-sea gorgonian corals Primnoa spp.: a new archive of surface processes. Mar Ecol Prog Ser 301:135-148

Smith KL, Kaufmann RS (1999) Long-term discrepancy between food supply and demand in the deep eastern North Pacific. Science 284:1174-1177

Smith KL, Kaufmann RS, Baldwin RJ (1994) Coupling of near-bottom pelagic and benthic processes at abyssal depths in the eastern North Pacific Ocean. Limnol Oceanogr 39:1101-1118

Stone RP (2006) Coral habitat in the Aleutian Islands of Alaska: depth distribution, fine-scale species associations, and fisheries interactions. Coral Reefs 25:229-238

Stoner AW (2003) What constitutes essential nursery habitat for a marine species? A case study of habitat form and function for queen conch. Mar Ecol Prog Ser 257:275-289

Suryan RM, Santora JA, Sydeman WJ (2012) New approach for using remotely sensed chlorophyll a to identify seabird hotspots. Mar Ecol Prog Ser 451:213-225
Thiem O, Ravagnan E, Fossa JH, Berntsen J (2006) Food supply mechanisms for cold-water corals along a continental shelf edge. J Mar Syst 60:207-219

Tissot BN, Yoklavich MM, Love MS, York K, Amend M (2006) Benthic invertebrates that form habitat on deep banks off southern California, with special reference to deep sea coral. Fish Bull 104:167-181

Ver Hoef JM, Boveng PL (2007) Quasi-Poisson vs. negative binomial regression: How should we model overdispersed count data? Ecology 88:2766-2772

Virtanen R, Oksanen J, Oksanen L, Razzhivin VY (2006) Broad-scale vegetation-environment relationships in Eurasian high-latitude areas. J Veg Sci 17:519-528

- Wagner D, Waller RG, Toonen RJ (2011) Sexual reproduction of Hawaiian black corals, with a review of the reproduction of antipatharians (Cnidaria: Anthozoa: Hexacorallia). Invertebr Biol 130:211-225

Wagner D, Luck DG, Toonen RJ (2012) The biology and ecology of black corals (Cnidaria: Anthozoa: Hexacorallia: Antipatharia). Adv Mar Biol 63:67-132

White M, Mohn C, Stigter H, Mottram G (2005) Deep-water coral development as a function of hydrodynamics and surface productivity around the submarine banks of the Rockall Trough, NE Atlantic. In: Freiwald A, Roberts JM (eds) Cold-water corals and ecosystems. Springer, Berlin, p 503-514

Willis BL, Oliver JK (1990) Direct tracking of coral larvae implications for dispersal studies of planktonic larvae in topographically complex environments. Ophelia 32: 145-162

> Wood SN (2000) Modelling and smoothing parameter estimation with multiple quadratic penalties. J R Stat Soc B Stat Methodol 62:413-428

- Wood SN (2004) Stable and efficient multiple smoothing parameter estimation for generalized additive models. J Am Stat Assoc 99:673-686

Woodby D, Carlile D, Hulbert L (2009) Predictive modeling of coral distribution in the Central Aleutian Islands, USA. Mar Ecol Prog Ser 397:227-240

Wright DJ, Heyman WD (2008) Introduction to the Special Issue: marine and coastal GIS for geomorphology, habitat mapping, and marine reserves. Mar Geod 31: 223-230

Xiu P, Chai F (2011) Modeled biogeochemical responses to mesoscale eddies in the South China Sea. J Geophys Res 116:C10006, doi:10.1025/2010JC006800

Xiu P, Chai F, Shi L, Xue HJ, Chao Y (2010) A census of eddy activities in the South China Sea during 1993-2007. J Geophys Res 115:C03012, doi:10.1029/2009JC005657

Xiu P, Chai F, Shi L, Xue HJ, Chao Y (2012) Modeling mesoscale eddy field in the Gulf of Alaska. Deep-Sea Res I 63: 102-117

Yesson C, Taylor ML, Tittensor DP, Davies AJ and others (2012) Global habitat suitability of cold-water octocorals. J Biogeogr 39:1278-1292

Yoklavich M, Love M (2005) Christmas tree corals: a new species discovered off southern California. J Mar Educ 21:27-30

Yoklavich MM, O'Connell V (2008) Twenty years of research on demersal communities using the Delta submersible in the Northeast Pacific. In: Reynolds JR, Green GH (eds) Marine habitat mapping technology for Alaska. Alaska Sea Grant, Anchorage, AK, p 143-155

Zuur AF, Ieno EN, Smith GM (2007) Analysing ecological data. Springer, New York, NY 
Appendix 1. Taxa (code and scientific and common names) used in the non-metric multidimensional scaling ordination (ordered by ascending depth). Bold names indicate taxa plotted in Fig. 7. Frequency of occurrence is the number of transect groups (out of 47 ) in which a given taxon occurred. Depth is the abundance-weighted average depth

\begin{tabular}{|c|c|c|c|c|}
\hline Code & Scientific name & Common name & $\begin{array}{c}\text { Frequency of } \\
\text { occurrence }\end{array}$ & Depth (m) \\
\hline Red Gorgonian & Leptogorgia chilensis & Red gorgonian & 5 & 62 \\
\hline HONEY RF & Sebastes umbrosus & Honeycomb rockfish & 10 & 81 \\
\hline SHEEPHEAD & Semicossyphus pulcher & California sheephead & 5 & 82 \\
\hline YTAIL & Sebastes flavidus & Yellowtail rockfish & 6 & 97 \\
\hline CRYPTO & Cryptotrema corallinum & Deepwater blenny & 15 & 99 \\
\hline ROSY RK & Sebastes rosaceus & Rosy rockfish & 18 & 101 \\
\hline OLIVE & Sebastes serranoides & Olive rockfish & 7 & 102 \\
\hline Z.ROSA & Zalembius rosaceus & Pink surfperch & 9 & 105 \\
\hline BGOBY & Rhinogobiops nicholsii & Blackeye goby & 28 & 106 \\
\hline SURFPERCH & Embiotocidae & Unidentified surfperch & 5 & 107 \\
\hline VERM RK & Sebastes miniatus & Vermilion rockfish & 23 & 108 \\
\hline SQSPOT RF & Sebastes hopkinsi & Squarespot rockfish & 32 & 116 \\
\hline MOSER & Sebastes moseri & Whitespotted rockfish & 15 & 117 \\
\hline STARRY & Sebastes constellatus & Starry rockfish & 31 & 118 \\
\hline RONQUL & Rathbunella spp. & Unidentified ronquil & 11 & 121 \\
\hline HALFBAND RF & Sebastes semicinctus & Halfbanded rockfish & 29 & 123 \\
\hline GSPOT RK & Sebastes chlorostictus & Greenspotted rockfish & 34 & 126 \\
\hline YOY & Sebastes spp. young-of-year & Juvenile rockfish & 38 & 126 \\
\hline PETRALE & Eopsetta jordani & Petrale sole & 5 & 127 \\
\hline PYGMY RF & Sebastes wilsoni & Pygmy rockfish & 32 & 128 \\
\hline SPECKLED RF & Sebastes ovalis & Speckled rockfish & 26 & 131 \\
\hline FLAG & Sebastes rubrivinctus & Flag rockfish & 28 & 131 \\
\hline YEYE RK & Sebastes ruberrimus & Yelloweye rockfish & 5 & 131 \\
\hline LINGCOD & Ophiodon elongatus & Lingcod & 30 & 133 \\
\hline BOCACCIO & Sebastes paucispinis & Bocaccio & 35 & 135 \\
\hline WIDOW RF & Sebastes entomelas & Widow rockfish & 21 & 142 \\
\hline Acanthogorgia & Acanthogorgia spp. & Gold coral & 11 & 146 \\
\hline Hex Oct Co & Hexacorallia/Octocorallia & Unidentified coral & 18 & 158 \\
\hline COWCOD & Sebastes levis & Cowcod & 32 & 158 \\
\hline P.VETU & Parophrys vetulus & English sole & 9 & 160 \\
\hline GSTRIPE RF & Sebastes elongatus & Greenstriped rockfish & 33 & 161 \\
\hline CUSK & Ophidiidae & Unidentified cuskeel & 18 & 164 \\
\hline R.INOR & Raja inornata & California skate & 5 & 167 \\
\hline SBELLY RK & Sebastes jordani & Shortbelly rockfish & 29 & 175 \\
\hline Primnoid & Plumarella longispina & Primnoid coral & 25 & 179 \\
\hline Sea Fan & Gorgonacea & Unidentified sea fan & 21 & 179 \\
\hline R.RHIN & Raja rhina & Longnose skate & 7 & 180 \\
\hline BIG SKATE & Raja binoculata & Big skate & 6 & 181 \\
\hline EOS & Sebastes eos & Pink rockfish & 6 & 184 \\
\hline CHILI RF & Sebastes goodei & Chilipepper rockfish & 9 & 184 \\
\hline Up Flat Sp & Porifera no. 2 & Upright flat sponges & 44 & 186 \\
\hline Thin Sea Pen & Pennatulacea & Thin sea pen coral & 29 & 187 \\
\hline SHARP RK & Sebastes zacentrus & Sharpchin rockfish & 6 & 188 \\
\hline H.COLL & Hydrolagus colliei & Spotted ratfish & 32 & 191 \\
\hline Styloco & Stylocordyla spp. & Stalked sponge & 6 & 197 \\
\hline DARKBL RF & Sebastes crameri & Darkblotched rockfish & 11 & 197 \\
\hline SCULP & Cottidae & Unidentified sculpin & 32 & 198 \\
\hline GBLOTCH RF & Sebastes rosenblatti & Greenblotched rockfish & 28 & 198 \\
\hline Foliose Sp & Porifera no. 1 & Foliose sponge & 42 & 198 \\
\hline STRIPETAIL RF & Sebastes saxicola & Stripetail rockfish & 14 & 202 \\
\hline PRICKLE & Stichaeidae & Unidentified prickleback & 13 & 204 \\
\hline Porife12 & Porifera no. 12 & Unidentified sponge & 15 & 205 \\
\hline BANK RF & Sebastes rufus & Bank rockfish & 33 & 214 \\
\hline Porife5 & Porifera no. 5 & Vase sponge & 43 & 218 \\
\hline Barrel Sp & Porifera no. 3 & Barrel sponge & 42 & 221 \\
\hline Cup Co & Scleractinia & Cup coral & 10 & 221 \\
\hline
\end{tabular}


Appendix 1 (continued)

\begin{tabular}{|c|c|c|c|c|}
\hline Code & Scientific name & Common name & $\begin{array}{l}\text { Frequency of } \\
\text { occurrence }\end{array}$ & Depth (m) \\
\hline Shelf Sp & Porifera no. 4 & Shelf sponge & 33 & 224 \\
\hline BRONZE RF & Sebastes gilli & Bronzespotted rockfish & 7 & 228 \\
\hline White Co & Lophelia pertusa & White coral & 13 & 233 \\
\hline POACHER & Agonidae & Unidentified poacher & 29 & 240 \\
\hline Branching Sp & Porifera no. 7 & Branching sponge & 18 & 243 \\
\hline Christmas Co & Antipathes dendrochristos & Christmas tree coral & 26 & 243 \\
\hline Cockscomb Co & Desmophyllum dianthus & Cockscomb coral & 8 & 246 \\
\hline Zoantha & Zoantharia & Zoanthid coral & 15 & 257 \\
\hline Pipecleaner Sp & Asbestopluma spp. & Pipecleaner sponge & 12 & 284 \\
\hline M.PACI & Microstomus pacificus & Dover sole & 17 & 289 \\
\hline Mound Sp & Porifera no. 6 & Mound sponge & 18 & 300 \\
\hline Vase Sp & Heterochone calyx & Fingered goblet vase sponge & 11 & 309 \\
\hline SPLITNOSE RF & Sebastes diploproa & Splitnose rockfish & 9 & 312 \\
\hline AURORA RF & Sebastes aurora & Aurora rockfish & 6 & 344 \\
\hline Porife8 & Porifera no. 8 & Tube sponge & 9 & 348 \\
\hline BLKGIL RF & Sebastes melanostomus & Blackgill rockfish & 5 & 364 \\
\hline Polymas & Polymastia spp. & Nipple foliose sponge & 5 & 377 \\
\hline Porife9 & Porifera no. 9 & Puffball mound sponge & 9 & 387 \\
\hline Farrea & Farrea occa & Lace foliose sponge & 8 & 392 \\
\hline Paragora & Paragorgia arborea & Bubblegum coral & 8 & 403 \\
\hline Stauroc & Staurocalyptus spp. & Picasso sponge & 8 & 412 \\
\hline HAGFSH & Eptatretus spp. & Unidentified hagfish & 12 & 422 \\
\hline Yellow Upright Sp & Mycale spp. & Yellow upright flat sponge & 9 & 426 \\
\hline Thenea & Thenea muricata & Clear foliose sponge & 5 & 430 \\
\hline Peppermint Co & Paragorgia spp. & Peppermint coral & 7 & 434 \\
\hline Soft Co & Clavularia spp. & Soft coral & 5 & 438 \\
\hline Mushroom Co & Anthomastus ritteri & Mushroom coral & 6 & 458 \\
\hline THORNYHEAD & Sebastolobus spp. & Unidentified thornyhead & 6 & 466 \\
\hline Yellow Swiftia & Plexauridae & Swiftia-type coral, red with yellow polyps & 5 & 481 \\
\hline
\end{tabular}

Editorial responsibility: Brian Helmuth, Nahant, Massachusetts, USA
Submitted: June 21, 2013; Accepted: October 9, 2013 Proofs received from author(s): November 19, 2013 